\title{
Information and Communication Technologies to Improve Problem Solving and Self- Efficacy: Exploring Geometry Learning Using Dynamic Mathematics Software Geogebra
}

Submitted 1 June 2021, Revised 29 June 2021, Accepted 31 July 2021

\author{
Mukhtar Mukhtar ${ }^{1,5^{*}}$, R. Ahmad Zaky El Islami ${ }^{2,6}$, Damanhuri Damanhuri ${ }^{3}$, Ferdinand Murni Hamundu ${ }^{4,7}$ \\ ${ }^{1}$ Department of Primary Education, Faculty of Teacher Training and Education, \\ Universitas Sultan Ageng Tirtayasa, Serang, Indonesia \\ ${ }^{2}$ Department of Science Education, Faculty of Teacher Training and Education, \\ University of Sultan Ageng Tirtayasa, Serang, Indonesia \\ ${ }^{3}$ Department of Civic Education, Faculty of Teacher Training and Education, \\ University of Sultan Ageng Tirtayasa, Serang, Indonesia \\ ${ }^{4}$ Faculty of Mathematics and Natural Science, Universitas Halu Oleo, Kendari, Indonesia \\ ${ }^{5}$ School of Mathematical Sciences, Universiti Sains Malaysia, Penang, Malaysia \\ ${ }^{6}$ Division of Science Education, Faculty of Education, Kasetsart University, Bangkok, Thailand \\ ${ }^{7}$ School of Computers Sciences, Universiti Sains Malaysia, Penang, Malaysia \\ Corresponding email: *mukhtar@untirta.ac.id
}

\begin{abstract}
Information and communication technologies can support learning of geometry through geogebra software. This study aimed to investigate the effectiveness of dynamic mathematics software geogebra towards problem solving and self-efficacy. Seventy-four university students divided to one class assigned as geogebra assisted learning and the other as using conventional learning. The results showed a significant difference of problem solving between these two groups statistically. Additionally, The results showed that there is a significant difference of selfefficacy between these two groups statistically. The results indicates that the problem solving and sef-efficacy of the university students using geogebra assisted better than using conventional learning. We can conclude that the dynamic mathematics software geogebra is effective to improve problem solving and self-efficacy.
\end{abstract}

Keywords: geogebra, problem solving, self-efficacy

\section{INTRODUCTION}

One of the challenges in mathematics teaching is assisting students to become skilled problem solvers, not memorizers (Granberg and Olson, 2015). It needs a comprehensive set of mathematical skills to solve the problems. However, many students have not acquired the basic skills in mathematics (Ali and Desa, 2004; Berch \& Mazzocco 2007). In the previous studies by Tay Lay Heong (2005), Tarzimah (2005), and Kiat (1995) found that many students have problems in mathematics problem solving. While, problem solving is an important part of mathematics teaching, so students should be given opportunities to practice problem solving on a regular schedule (Kilpatrick, Swafford, \& Findell, 2001).

Problem solving is important in math classes, because one of the purposes of teaching mathematics is to improve students' problem-solving skill which could be used in daily life activities (Yilmaz, 2007). The advancements of mathematics area demonstrate that students should develop their problem-solving skills. As Sahin (2007) found that the students who develop their ability and habit of problem solving during their school years become individuals 
who can handle problems in the community in the future. Beside problem solving, students also need self-efficay in daily life to support their problem solving.

In education, self-efficacy has been widely applied (Beas \& Salanova, 2006). The concept of self-efficacy was widely applied in Social Cognitive (Bandura, 2001). In this way, self-efficacy produces beliefs in cognitive, affective, motivational, and selective processes (Bandura, 1997).

El Islami, et al (2015) implemented the inquiry learning to improve the self - efficacy of the university students, the report of this study is there is an improvement of self -efficacy of students by inquiry learning, but not difference statistically to conventional learning. Another previous study, El Islami et al (2015) correlate the self-efficacy with scientific literacy, the report of this study is there is no correlate between self-efficacy with scientific literacy. According to Damanhuri, Hakim, and Mukhtar (2015) state that self-efficacy also affects the achievement of learning. This previous study in line with Wolters \& Rosenthal, (2000) that found that students with higher levels of self-efficacy set higher purposes, employ more effort, persist longer in the face of challenge and are more liable to apply self-regulated learning approaches.

In mathematics, self - efficacy refers to the believeness to perform mathematics successfully (Burnham, 2011). Efficacy in mathematics is essential and in our technological society, self - efficacy plays an important role (Anthony and Walshaw 2007). Mathematics self-efficacy is a student's assessment of ability to solve problem successfully in the areas of geometry, arithmetic, measurement, and algebra (Bandura and Schunk 1981; Schunk and Pajares 2009). In this study, we will focus on geometry teaching that use geogebra.

In a traditional geometry instruction, students do not discover geometric relationship, nor invent any mathematics (Maragos, 2004). Students can improve their geometry thinking skills in student - centered learning environments especially in geogebra (Battista, 2002). Issue in mathematics education, computer's roles should not be limited to teaching.

In the previous studies, Joubert (2013) used Geogebra software to support problem solving and conceptual understanding. Geogebra software can refer to concrete mathematical objects like geometric figures, algebraic expressions, and graphs (Sedig \& Sumner, 2006). Geogebra software offers educators a resourceful teaching environment in which educators can create new ways to connect, extend, and enrich their instructional activities in order to improve student's understanding of mathematics concepts (Xistouri and Pitta-Pantazi, 2013). 
Based on the gap, it is importan to conduct a research on geogebra, problem solving and self-efficacy. So, this study is aimed to to investigate the effectiveness of dynamic mathematics software geogebra towards problem solving and self-efficacy

\section{METHOD}

\section{Design of the study}

This study used a quasi-experimental method. This study will investigate the effectiveness of dynamic mathematics software geogebra towards problem solving and self-efficacy using experimental and control classess with design in Table 1.

Table 1. Nonequivalent pretest-posttest control group design

\begin{tabular}{llll}
\hline Group & \multicolumn{3}{l}{ Independent Variable } \\
\hline Geogebra assisted (E) & Y1 & X & Y2 \\
Convensional (C) & Y1 & --- & Y2 \\
\hline
\end{tabular}

Note:

$\begin{array}{llll}\text { E }- \text { Geogebra assisted } & \text { Y1 }- \text { pretest } & \text { X } & \text { GeoGebra Teaching Strategy (GTS) } \\ \text { C }- \text { Convensional } & \text { Y2 }- \text { posttest } & -- & \text { Conventional Teaching Strategy (CTS) }\end{array}$

\section{Research Procedure}

This study was conducted in the 2016-2017 academic year with 74 university students who had taken a course about mathematics education software during a year at one public university in Indonesia. They had learned to use Geogebra softwares in the second semester. They participated weekly in two-hour lessons and they were asked to prepare Geogebra software activities weekly in one semester or 15 meetings. The instructor of provided extra guidance to the students in case they needed help during learning. Problem solving close-ended questionnaire was used to measure the university students' problem solving, and self-efficacy questionnaire to measure the the university students' self-efficacy

\section{Data Analyses}

The data of pretest and postest of problem solving between experimental and control classess will be calculated. Also, the data of pretest and postest of self-efficay between experimental and control classess will be calculated. Data of pretest both problem solving and self-efficacy between experimental and control classess will be tested to investigate the difference between those two classes statistically. After that the data of posttest both problem solving and self-efficacy between experimental and control classess will be tested to investigate the difference between those two classes statistically. This postest data will be used to investigate the the effectiveness of dynamic mathematics software geogebra towards problem solving and self-efficacy. 


\section{RESULTS AND DISCUSSION}

Descriptive statistics and statistically test associated with the mean value of mathematical problem-solving skills are summarized in this section. The researchers compared the problem-solving abilities between students using learning with Geogebra assisted and conventional.

\section{Problem Solving Ability}

\section{Statistic Descriptive}

Data obtained and analyzed in this study include the problem solving of pretest and posttest in the experimental and control classes.

Table 2. Descriptive statistics pretest and posttest

\begin{tabular}{|c|c|c|c|c|c|c|c|c|c|}
\hline \multirow[t]{2}{*}{ Test } & \multicolumn{4}{|c|}{ Geogebra assisted } & \multicolumn{4}{|c|}{ Conventional } & \multirow{2}{*}{$\begin{array}{l}\text { Maximum } \\
\text { Score }\end{array}$} \\
\hline & $\mathrm{N}$ & $\mathrm{X}_{\text {Min }}$ & $X_{\text {Mak }}$ & $\breve{X}$ & $\mathrm{~N}$ & $\mathrm{X}_{\text {Min }}$ & $\mathrm{X}_{\text {Mak }}$ & $\breve{X}$ & \\
\hline Pretest & 36 & 8 & 30 & 18.58 & 38 & 4 & 38 & 20.15 & 100 \\
\hline Postest & 36 & 38 & 68 & 50.31 & 38 & 34 & 56 & 39.34 & 100 \\
\hline
\end{tabular}

Table 2 shows that the mean value of pretest of mathematical problem-solving ability of conventional learning is better than Geogebra assisted, the difference is about 1.57. Then after the post-test the average value of the Geogebra assisted group is greater than the conventional learning with the difference around 10.97.

\section{Pretest}

The statistical results for the pretest of problem solving of both experimental and control classes are shown in Table 3:

Table 3. Results of the independent $t$-test on the pretest of problem solving of both experimental and control classes.

\begin{tabular}{lllll}
\hline \multicolumn{5}{c}{ Pretest } \\
\hline Classs & Mean & S. D. & $t$-value & Sig (2 tailed) \\
\hline Experimental (36) & 18.58 & 4.58803 & -1.208 & .231 \\
Control (38) & 20.15 & 6.42010 & & \\
\hline
\end{tabular}

As it was expected, the difference between the tested groups, Experiment and Control, was not statistically significant at the level of significance of $0.05(\mathrm{t}=-1.208 ; \mathrm{p} .231)$.

Thus, from the data analysis of the average of pretest that has been done, it can be concluded that the initial ability in the mathematical problem-solving ability aspects of students to geogebra-assisted groups and conventional learning groups equivalent before being given done.

\section{Posttest}

The results of the independent $t$-test on the posttest of both groups that can be seen in Table 4. 
Table 4. Results of the independent $t$-test on the post test of problem solving both experimental and control classes.

\begin{tabular}{lllll}
\hline & \multicolumn{3}{c}{ Posttest } \\
\hline Class & Mean & S. D. & $t$-value & Sig (2 tailed) \\
Geogebra Assisted (36) & 50.3056 & 6.98905 & 7.784 & .000 \\
Control (38) & 39.3421 & 5.01498 & & \\
\hline
\end{tabular}

An independent samples t-test was conducted to compare the groups' posttest scores between Geogebra assisted and conventional. There was a statistically significant difference between the Geogebra assisted (Mean $=50.3056, S D=6.98905)$ and the conventional (Mean $=39.3421, S D=5.01498 ; t(36)=4.83, p<.05$, two-tailed) in terms of problem solving mathematics.

\section{Self-Efficacy}

As shown in Table 5, to find out the mean value of self-efficacy between experiment and conventional classes.

Table 5. Results of self-efficacy of the independent $t$-test on the posttest of self-efficacy of both experimental and control classes.

\begin{tabular}{llcll}
\hline & \multicolumn{3}{c}{ Self-Efficacy } \\
\hline Class & Mean & S. D. & $t$-value & Sig (2 tailed) \\
Geogebra Assisted (36) & 79.2500 & 8.06890 & 2.764 & .007 \\
Control (38) & 74.3947 & 6.96532 & & \\
\hline
\end{tabular}

The self-efficacy mean score of the experiment students is 79.25 with standard deviation of 8.068 , while that of the conventional is 74.3947 with standard deviation of 6.96 . The difference between the experiment and conventional mean scores is 28.30 . Then the mean value of self-efficacy for the experiment class is more diffuse compared to the conventional class. This is evident from Table 5 with $\mathrm{t}=2.764, \mathrm{p}=.007$. The implication is that there is significant difference between the self-efficacy mean scores of experiment and conventional students. This results indicates that the dynamic mathematics software geogebra is effective to improve self-efficacy. Self-efficacy as attitude is can be supported by application of computer assisted instruction enriched with use of geogebra as Aiken (1972) found.

The purpose of this research is to investigate the effectiveness of dynamic mathematics software geogebra to problem solving and self-efficacy. The results showed that based on group approach of learning, there is a significant difference between the problem-solving ability of mathematics students who follow the learning with Geogebra assisted and students who follow conventional learning. This results indicates that the dynamic mathematics software geogebra is effective to improve problem solving. This results can be supported by 
Barron et al. (2007) that found that the geogebra software can make the powerful mathematical ideas that it uses to reformulate or create new ways of knowledge. In some literatures, the Geogebra assisted students in creating multiple representations of geometrical concepts and assisted avoid algebraic obstacles, allowing students to focus on geometric understanding (Iranzo \& Fortuny, 2011). Another previous study Maricic, (2010) found that the geogebra is a well-suited study environment for problem solving

\section{CONCLUSION}

Based on the results we can conclude that the dynamic mathematics software geogebra is effective to improve problem solving and self-efficacy.

\section{REFERENCES}

Aiken, L. R. (1972). Research on attitudes toward mathematics. Arithmetic Teacher, 229-234.

Anthony, G., \& Walshaw, M. (2007). Effective pedagogy in mathematics/pangarau: best evidence synthesis iteration (BES). Wellington: Ministry of Education.

Bandura, A. (1997). Self-efficacy: The exercise of control. New York, NY: Freeman.

Bandura, A., \& Schunk, D. H. (1981). Cultivating competence, self-efficacy, and intrinsic interest through proximal self-motivation. Journal of Personality and Social Psychology, 41(3), 586.

Bandura, A. (2001). Social cognitive theory: an agentic perspective. Annual Review of Psychology, 51, 1-26.

Barron, B., Martin, C. \& Roberts, E. (2007). Sparking self-sustained learning: report on a design experiment to build technological fluency and bridge divides. International Journal of Technology and Design Education, 17(1), 75-105.

Battista, M. (2002). Learning geometry in a dynamic computer environment. Teaching Children Mathematics, 8(6), 333-338.

Beas, Maria Isabel \& Salanova, Marisa (2006). Self-efficacy beliefs, computer training and psychological well-being among information and communication technology workers

Berch, D.B. \& Mazzocco M.M.M. (2007). Why is math so hard for some children? The Nature and Origins of Mathematical Learning Difficulties and Disabilities. Maryland: Paul H. Brookes Publishing Co.

Burnham, J. R. (2011). A case study of mathematics self-efficacy in a freshman engineering mathematics course. Unpublished master's thesis, Washington State University, USA

Damanhuri, Lukman Nulhakim, Mukhtar (2015). Hubungan Self-Efficacy Dosen Dengan SelfEfficacy Mahasiswa Yang Sedang Menyusun Skripsi Di Semester Ganjil 2015/2016 Universitas Sultan Ageng Tirtayasa 
El Islami, R. A. Z, Nahadi, Permanasari, A. (2015). Membangun Kepercayaan Diri Siswa melalui Pembelajaran Inkuiri Terbimbing pada Konsep Asam Basa. Edusains. Vol. 7, No.1: 64-69

El Islami, R. A. Z, Nahadi, Permanasari, A. (2015). Hubungan Literasi Sains Siswa dan Kepercayaan Diri Siswa pada Konsep Asam Basa. Jurnal Penelitian dan Pembelajaran IPA. Vol.1, No.1: 16-25.

Granberg, Carina \& Olsson, Jan (2015). ICT-supported problem solving and collaborative creative learning: Exploring linear function using dynamic mathematics software.

Joubert, M. (2013). Using computers in classroom mathematical tasks: revisiting theory to develop recommendations for the design of tasks. Task Design in Mathematics Education. Proceedings of ICMI Study 22, 69.

Kilpatrick, J., Swafford, W., \& Findell, B. (2001). Adding it up: Helping children learn mathematics. Washington, DC: National Academy Press.

Kiat, Lim See.(1995). Pola Pemikiran dalam Proses Penyelesaian Masalah Matematik Berperkataan di Kalangan Murid-murid Tahun Enam KBSR. Tinjauan Tiga Buah Sekolah Kebangsaan di kawasan Ulu Kelantan. Kelantan: Unit Matematik, Maktab Perguruan Kota Bahru.

Maricic, Kaja (2010) Problem solving using GeoGebra - the case of geometry, Mechanical Engineering High School Novi Sad, Serbia

Maragos, C. (2004). Building educational scenarios with "Sketchpad." Retrieved from http://hermes.di. uoa.gr/edugames/sketchpad/ScetchPad.pdf.

Ali, Mohd Nizam \& Desa, Rosaznisham.(2004). Meningkatkan Kemahiran Mengingat Sifir 3,6 dan 9 di Kalangan Murid Pemulihan Tahap 2. Jurnal Kajian Tindakan Pelajar PSPK. Kementerian Pendidikan Malaysia, $102-112$

Iranzo, N and Fortuny, Josep Maria (2011). Influence of geogebra on problem solving strategies: processing mathematics through digital technologies page 91-97

Sahin, A. A. (2007). Determining the problem solving strategies for the students aged 13-14 years. Master

Sedig, K., \& Sumner, M. (2006). Characterizing interaction with visual mathematical representations. International Journal of Computers for Mathematical Learning, 11(1), $1-55$.

Schunk, D. H., \& Pajares, F. (2009). Self-efficacy theory. Handbook of motivation at school,35-53.

Tarzimah. (2005). Penggunaan Kaedah Nemonik Berirama dalam Pembelajaran Matematik bagi Pelajar Lemah: Satu Kajian kes. Tesis Sarjana. Universiti Kebangsaan Malaysia. Thesis. Balikesir University, Institute of Natural Sciences, Balikesir. 
Tay Lay Heong. (2005). Problem Solving Abilities and Strategies in Solving Multistep Mathematical Problems among Form 2 Students. Kertas Projek Sarjana. Universiti Malaya.

Wolters, C.A.\& Rosenthal, H.(2000). The relation between students' motivational beliefs and their use of motivational regulation strategies. International Journal of Education Research, 33 (7-8), 801-820.

Xistouri, Xenia \& Pitta-Pantazi, Demetra (2013). Using GeoGebra to develop primary school students' understanding of reflection

Yilmaz. K. (2007). Survey about affect of epistemological beliefs and beliefs about mathematical problem solving on problem solving process. Master Thesis, Marmara University. Institute of Educational Sciences, Istanbul. 